First Peoples Child \& Family Review

A Journal on Innovation and Best Practices in Aboriginal Child Welfare Administration,

Research, Policy \& Practice

\title{
Rethinking Social Work Education for Indigenous Students: Creating Space for Multiple Ways of Knowing and Learning
}

\section{Nicole G. Ives, Oonagh Aitken, Michael Loft and Morgan Phillips}

Volume 3, Number 4, 2007

URI: https://id.erudit.org/iderudit/1069370ar

DOI: https://doi.org/10.7202/1069370ar

See table of contents

Publisher(s)

First Nations Child and Family Caring Society of Canada

ISSN

1708-489X (print)

2293-6610 (digital)

Explore this journal

Cite this article

Ives, N., Aitken, O., Loft, M. \& Phillips, M. (2007). Rethinking Social Work Education for Indigenous Students: Creating Space for Multiple Ways of Knowing and Learning. First Peoples Child \& Family Review, 3(4), 13-21. https://doi.org/10.7202/1069370ar
Article abstract

McGill University School of Social Work initiated a research project in October 2005 to examine the social work education and ongoing professional needs of the First Nations communities of Kahnawake and Kanehsatake. These communities had previously been served by a 30 -credit certificate program. Using qualitative methodology, the project sought to gather data which would eventually assist in the development of a curriculum and pedagogical approach that would reflect the social and cultural reality of these communities as part of the regular BSW program. This paper describes the process, key findings, and potential next steps for the School. viewed online. 


\title{
Rethinking Social Work Education for Indigenous Students: Creating Space for Multiple Ways of Knowing and Learning
}

\author{
Nicole G. Ives ${ }^{a}$, Oonagh Aitken ${ }^{b}$, Michael Loft ${ }^{c}$ and Morgan Phillips ${ }^{d}$
}

A Nicole G. Ives, Ph.D., Assistant Professor, McGill University School of Social Work, nicole.ives@mcgill.ca, Telephone: (514) 398-7065, Fax: (514) 398-4760. Nicole Ives is an Assistant Professor in the School of Social Work at McGill University. Her current research and teaching interests lie in the areas of indigenous social work education and refugee studies. Dr. Ives is currently conducting research social work education for First Nations and Inuit communities in Canada.

${ }^{b}$ Oonagh Aitken, M.A. M.Ed., Coordinator, Indigenous Access McGill, McGill University School of Social Work, oonagh. aitken@mcgill.ca, Telephone: (514) 398-7057, Fax: (514) 398-4760. Oonagh Aitken has a background in local government management and social policy. Currently she is a sessional lecturer in the School of Social Work and is involved in a number of projects including research into social work education for First Nations and Inuit communities and access to health and social services for minority Anglophone communities.

${ }^{\mathrm{c}}$ Michael Loft, M.S.W., Professional Associate, Indigenous Access McGill, McGill University School of Social Work, michael. loft@mcgill.ca, Telephone: (514) 398-2129, Fax: (514) 398-4760. Michael Loft is a member of the Turtle Clan and resides in the Mohawk community in Kahnawake. He has 24 years of front-line experience in Native Child-Protection and in private practice and is currently a professional associate in the School of Social Work at McGill University. Aside from his teaching duties, his research activities and interests are in the area of First Nations social work education and Indigenous healing.

${ }^{d}$ Morgan Phillips, B.A., Research Associate, kahentonni@yahoo. ca, Morgan Kahentonni Phillips is a Mohawk from the community of Kahnawake and is from the Wolf clan. She will be graduating with a B.A. Honours in Anthropology at Concordia University, Montreal, and plans to pursue graduate studies in the fields of Sociology and Anthropology. She is currently a Community Researcher with the National Network for Aboriginal Mental Health Research at the Montreal Jewish General's Culture \& Mental Health Research Unit. She is also a member of the First Nations \& Inuit Steering Group at McGill University and is a member of Kahnawake's Health \& Social Services Research Council, Onkwata'karitáhtsera.

The authors are grateful for the support of the Ministère de l'Education, du Sport et du Loisir du Québec for the project on which this article is based.

() Nicole G. Ives, Oonagh Aitken, Michael Loft and Morgan Phillips

\begin{abstract}
McGill University School of Social Work initiated a research project in October 2005 to examine the social work education and ongoing professional needs of the First Nations communities of Kahnawake and Kanehsatake. These communities had previously been served by a 30 -credit certificate program. Using qualitative methodology, the project sought to gather data which would eventually assist in the development of a curriculum and pedagogical approach that would reflect the social and cultural reality of these communities as part of the regular BSW program. This paper describes the process, key findings, and potential next steps for the School.
\end{abstract}

\section{Introduction}

The development of Indigenous social work education in Canada began in the early 1970s. In 1974, Maskwachees Cultural College was formally established by the Four Bands of Hobbema (Alberta). The College created an Aboriginal Social Work Diploma program. Saskatchewan Indian Federated College (SIFC), established in 1976, offered Social Work as one of six programs (in 2003, SIFC changed its name to the First Nations University of Canada School of Indian Social Work). Currently, there are 4 programs offering an adapted Aboriginal Bachelor of Social Work degree across the country (Nicola Valley Institute of Technology in association with Thomson River University, University of Manitoba, First Nations University of Canada - School of Indian Social Work, and Dalhousie University). For the purposes of this study, we have defined social work education as accredited courses and programs offered in academic institutions across the country leading to a recognized professional qualification. In terms of terminology used in this paper, the research team agreed on the interchangeable use of First Nations, Indigenous, and Native to describe the descendents of peoples living in Canada prior to the arrival of the Europeans. This decision on terminology reflects the collaboration 
between First Nations researchers and Allied ${ }^{1}$ researchers in our study. From its inception, we collaborated as a team in spirit and application.

From 1995-2005, the McGill School of Social Work offered the Certificate in Aboriginal Social Work Practice and the Certificate in Northern Social Work Practice aimed at people currently employed by the social work agencies in the First Nations territories of Kahnawake and Kanehsatake and the Inuit territory of Nunavik. The Certificate was a 30 -credit program. Students were able to participate in a range of curriculum modules (10) worth 3 credits each. After completion of the Certificate, students could transfer their certificate credits to the regular BSW program. The course topics were designed collaboratively by Indigenous and allied social workers to address issues relevant to Indigenous communities. The academic year 2005-2006 saw the last cohort of students engage in modules to complete the certificates.

In 2006, the McGill School of Social Work initiated a research study to explore current social work education and ongoing professional development needs in the communities of Kahnawake, Kanehsatake and Nunavik. The Ministère de l'Education, du Sport et du Loisir du Québec funded the study designed to gather information on social work issues facing Indigenous communities traditionally served by McGill School of Social Work. The study was also designed to investigate participants' experience of the certificate program, explore their perceptions of the social issues facing their communities, discuss barriers to involvement in University level programs and gather views on program content and delivery which would prepare students for problemsolving work in their own communities. Interviewees were also asked their views on ways in which the School of Social Work could attract more Indigenous students to the BSW program. The study addressed a persistent gap in knowledge regarding social work education needs in Indigenous communities and the ways in which one could increase the enrollment in social work education by Indigenous students.

This paper is focused on the findings from the interviews of First Nations' participants (from Kahnawake and Kanehsatake). The research team overseeing the study was composed of McGill School of Social Work and Kahnawake community members, meeting First Nations' goals of building capacity and knowledge within Indigenous communities. Researchers interviewed Certificate graduates, community members and other key stakeholders to determine the ways in which the McGill School of Social Work could contribute to social work education and continuing professional development opportunities needs in these communities.
The first section of the paper describes the methods and the study's qualitative approach. The second section presents the findings that illustrate ways in which participants wanted curriculum and program delivery to be adapted to their cultural context. The final section includes a discussion of implications for this adaptation and future plans for the BSW program at the McGill School of Social Work as well as continuing education offered by the School.

\section{Project Context}

In the past 20 years, certain Indigenous communities have been able to assume responsibility for and management of their own community services. For example, in Manitoba child and family services to Indigenous people are provided through three organizations: Métis Child and Family Services Authority, First Nations of Southern Manitoba Child and Family Services Authority and First Nations of Northern Manitoba Child and Family Services Authority.

In the case of Kahnawake, responsibility and management includes the provision of community social services. The Band Council gained control of community services in 1985 and since then has gradually been developing a range of services to the community from family support to youth protection and care of Elders. Historically, non-Native social workers predominated in community services in Native communities because there was a dearth of professionally qualified Native social workers from the community itself. The certificate program operated by McGill until 2005 was able to fill a gap in terms of community workers but, like other certificate or training programs (see Smith \& Pace, 1988), the certificate program was not a degree program that offered a professional qualification.

Providing culturally relevant education (in curriculum and program delivery) to members of Native communities is a critical piece in the restoration of autonomy in social service provision in Native communities (O'Brien \& Pace, 1990; Weaver, 1999). It is essential to transform educational opportunities for Native students by developing different approaches to learning. Members of Native communities have underscored the need to increase social work education, both degree programs as well as ongoing professional education in ways that are relevant to Indigenous realities (Bruyere, 1998). A reality for the Indigenous communities in Quebec is that there are limited opportunities for participation in social work education. There are myriad challenges to address: logistics, linguistics, cultural distance, racism, and a history of distrust engendered by colonialism (Ryan, 1995). In addition, social work programs have 
been regarded as providing only a Western, Eurocentric perspective which does not reflect the political, social or cultural realities of Indigenous communities.

Community input is vital to the emancipatory project in which schools of social work should be involved in order to ensure that social workers operating in Native communities are, first and foremost, members of these communities and, equally importantly, have followed an appropriate professional education. By this, we mean that they have had access to a curriculum which reflects their own cultural and social reality, which uses a range of pedagogical approaches, including traditional ways of learning and knowing, which involves the advice and teaching of community Elders and which, if appropriate is delivered in a community setting. By offering this type of curriculum and pedagogy can schools of social work genuinely participate in a process that will contribute to the decolonizing project of combating structural oppression of Native peoples (Lee, 1992). The research study described in this paper continues the process begun by the Certificate program of the McGill School of Social Work towards such a pedagogy.

Keeping in mind that "the standard for social work education and practice is literature and education based on the worldview, lifeways, and reality" of the dominant mainstream (Sinclair, 2004, p. 53), one of the goals of the project was to explore the types of curriculum and program design that would be culturally relevant in Indigenous communities for Indigenous people. Programs that have an Indigenous perspective have adopted models shaped by the uniqueness of Indigenous world views and traditions, a holistic approach to social welfare as well as the need to address the historical and contemporary impact of colonization on Indigenous consciousness (Morrisette, McKenzie, \& Morrisette, 1993; Warner, 2006).

\section{Methodology}

The exploratory nature of the study called for a qualitative approach in order to gain knowledge of individuals' experiences and perceptions rather than "categorizing their experiences out of context" (Omidian, 2000, p. 42). Qualitative methods were chosen to allow interviewees to give voice to their own thoughts, providing insight into program experiences by Certificate participants and graduates as well as perceptions of social work needs in First Nations communities by community members themselves (Lieblich, Tuval-Mashiach, \& Zilber, 1998). Additionally, using a qualitative approach could increase the opportunity to have more personal and interactive communication and decrease the typical power relationships found in conventional research.
A Steering Group was formed to comment upon and direct the study in its various stages. The Steering Group was composed of members of the School of Social Work Faculty, instructors from the Certificate programs, Inuit and First Nations BSW and MSW students, practicing social workers with experience in the field of Indigenous social work and the research team. The Steering Group met throughout the study every 6 weeks to guide each step of the methodology.

\section{Sample}

Thirty-six participants were interviewed from the Mohawk communities of Kahnawake and Kanehsatake. There were 28 women and 6 men; 7 were graduates of the McGill Aboriginal Certificate Program and 7 had taken part in some of the certificate courses; and 22 were community members. Purposive and snowball sampling were used in partnership with First Nations community organizations to ensure the distribution of demographic and theoretical variables.

Criteria for participation in the study included having graduated from the Certificate program or having participated in one or more courses, holding a post in the Kahnawake or Kanehsatake community infrastructure with a link to social work, having a key stake in the community as a leader, an Elder or an interested community member. While the first criterion was easy to establish from School of Social Work records, and the second could be established through the community institutions, the two Indigenous researchers were given the freedom to apply the third criterion through their community knowledge.

\section{Data Sources/Data Collection/Data Analysis}

The primary data source was an in-depth, face-toface, individual interview guided by a semi-structured, open-ended interview schedule with explanatory, interpretative, and evaluative questions. This format allowed for the creation of new categories to emerge from the data (Padgett, 1998). The questionnaire focused on barriers to Indigenous students' success, course content appropriate to Indigenous reality, conceptualizations of social work, and the future of social work education. Interviews, audiotaped with permission, lasted approximately 60 minutes. Background demographic information was also gathered (see Appendices 1 and 2).

The study also aimed to contribute to the research capacity of the First Nations community. Toward this aim, two researchers from the Kahnawake community were hired to conduct all interviews in Kahnawake and Kanesehtake. This arrangement had its advantages since the two were cultural insiders. Although they enjoyed 


\section{Rethinking Social Work Education for Indigenous Students}

special epistemic privileges and conducted their work without too much difficulty, we must consider that this is not always the case. Historically, research has been considered "... one of the dirtiest words in the Indigenous world's library" (Tuhiwai-Smith, 1999, p. 1). This point was not lost on the researchers who did their utmost to traverse this delicate terrain in a respectful manner. One of the challenges faced by community researchers was ensuring that a satisfactory reciprocal process was put in place where participants could have the opportunity to view preliminary data results and make suggestions that reflected their views correctly. Indigenous researchers have a dual responsibility of satisfying both the academy and their communities as the "field" is also their home.

The Kahnawake Research Council and the McGill Research Ethics Board approved the study. The project also had to satisfy the ethical standards developed by the communities themselves. This required meeting with and presenting the project to the Kahnawake Community Research Council and to community leaders in Kanehsatake. The Kahnawake Research Council is made up of community members from Kahnawake, Quebec. The Council, which dates back to 2001, was originally developed to attend to numerous external requests to conduct research within the Territory of Kahnawake. The primary role of the Research Council is to safeguard the community from individuals who come with agendas that disadvantages the community. The Council's other task is to ensure the community receive some benefit from the research.

Content analysis was used for analyzing data. Conducting line-by-line analyses of interview transcripts (transcribed verbatim), units of content were gathered, coded, and interpreted descriptively and then assigned to thematic categories that emerged, following the grounded theory approach (Glaser \& Strauss, 1967). Members of the McGill/Kahnawake research team met together to discuss interview data and emerging themes, adding to the credibility of the findings.

\section{Findings}

In order to provide feedback to participants as well as the community, a community consultation was held in Kahnawake to present study findings. All study participants were invited as well as other community leaders and people working in the health and social services. The purpose of the consultation was to share the emerging findings of the research with the community and to gather additional views which would supplement the data. The results of the research project and the implementation of the recommendations that flow from the community in terms of developing social work education are crucial in providing social services that are relevant in a local community context (Gray, 2005).

Throughout the interviews, a common thread was the urgent need for professionally educated social work practitioners from Native communities working in Native communities. Underscored was the need to have Native approaches to learning and Native instructors. Although two participants referred specifically to a "Mohawk philosophy" in guiding social work practice, the majority spoke more generally about the necessity of having instructors from diverse First Nations communities, not specifically those that are Mohawk. Participants also felt there was a need for specific Native content in the curriculum. They felt it was critical to offer courses that covered diverse, contemporary First Nations issues and Native approaches to social work practice as well as incorporated Elder wisdom. The curriculum should be grounded in First Nations philosophy, values, and traditions.

Regarding program delivery, some participants wanted the courses conducted in Native communities, while others felt that it was important for students to travel to the McGill campus in Montreal. The majority, however, voiced a preference for a blended version of program delivery, where a portion of the program would be in the community while the remainder of the program would be on McGill's downtown campus.

\section{Teaching and Learning}

Who teaches the courses on Indigenous topics? There was a clear trend throughout the interviews that it was crucial to have Native instructors teaching Native topics. Some participants called attention to the need for non-Native social work students to attend courses on Native topics if they were going to be working in Native communities.

$$
\begin{aligned}
& \text { If it is somebody who is going to be teaching } \\
& \text { us and training us, it would have to be a Native } \\
& \text { person. A Native person knows the community, } \\
& \text { knows what approaches would have to be given } \\
& \text { to the community, know our manners of practice } \\
& \text { in dealing with the outside system, such as the } \\
& \text { court system. It would almost have to be, if there } \\
& \text { was specific training that the McGill School of } \\
& \text { Social Work would like to give, it would have } \\
& \text { to be something that would be community and } \\
& \text { culturally oriented and it would have to be } \\
& \text { given by a person who was a Native person. } \\
& \text { [Participant } 01]
\end{aligned}
$$

All participants mentioned the need for Elder involvement in a social work program focused on Native issues. For some participants, Elder involvement consisted of active participation in courses; for others, it 


\section{First Peoples Child \& Family Review, Volume 3, Number 4, 2007}

consisted of utilizing Elders' wisdom by integrating it into the curriculum. Subsequent discussion with colleagues in Schools of Social Work offering specializations in Native social work suggests that Elders can be integrated in a variety of ways, such as mentors to the students at specific times during the program, as instructors during a cultural immersion session, as co-instructors for particular courses or just simply to be on hand in the School for consultation. Incorporating Elder wisdom was part of a broader call to bring in traditional values to underscore the uniqueness of a Native approach to social work practice. Participants saw Elder-protected traditional values such as natural helping, consensus building, and healing as foundational to Native social work practice. One participant described social work as

looking at our problems coming from a natural
way. Our people have always been natural
helpers and natural counselors. That is the
work we have done and especially looking at
the areas within the clan system and each one
has their own way of being a counselor, being a
teacher, a person who would go and intervene in
whatever situation that is happening at the time.
[Participant 02]

The close-knit community of the Certificate program students was something that the participants had valued. Participants often mentioned how participating with other First Nations students had been "empowering" and had bolstered their self esteem.

Participants wanted to see a Native approach to teaching applied to Native issues. Their vision of this was a holistic experience that not only included Native content but a Native approach to learning. One participant described the beginning of a Native program in Ontario:

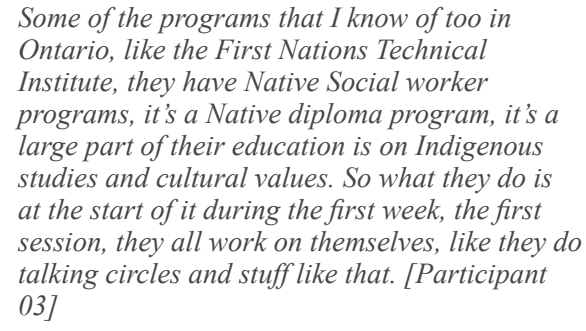

Aligning a Native pedagogy with Native-focused curriculum content would be an essential piece of a social work program that focused on Native issues. Such an approach would give credibility to the delivery of the content and show a respect for an Indigenous way of being and learning.

\section{Course Content}

Participants recounted numerous social issues facing their communities which they felt social workers needed to address. Some of these issues are also faced by non-Native communities, such as substance abuse, though participants believed that learning about and understanding the Native context was critical to addressing the issues effectively. Participants wanted to see courses or parts of courses devoted to understanding the ways in which the historical trauma experienced by Native peoples plays out in the current social, economic, and political context. Attention needed to be paid to the generational implications of colonialism, specifically residential schools.

Substance abuse was mentioned frequently as a crisis issue participants saw in their communities; addiction involving crystal methamphetamines was explicitly noted by several participants. Child abuse and neglect, including child sexual abuse, was cited by a majority of participants as a central issue tearing apart Native communities. Many specifically mentioned the importance of teaching traditional healing as part of a Native social work program. Participants also felt that Youth Protection needed to be better understood both its role and its history in the community as well as current legal issues important for social workers. One participant felt that without the knowledge of how the system worked, Native people involved in youth protection had a distinct disadvantage:

$$
\begin{aligned}
& \text { And giving more information on youth } \\
& \text { protection, that was rarely discussed in the } \\
& \text { program. Like I said, although we want to work } \\
& \text { with our own community, we still need to know } \\
& \text { about the other side and without having that } \\
& \text { knowledge, then they still have the upper hand } \\
& \text { on us because we still have to do what they say. } \\
& \text { We don't want to do that, you know, we don't } \\
& \text { want to do that. [Participant 04] }
\end{aligned}
$$

Other issues needing attention in Native communities were bullying, mental and physical health, particularly nutrition-related diseases, and the creation of healthy leaders in First Nations communities who could assist people on the political and social spectrum.

While participants voiced the necessity of having social work curriculum content that focused on Native issues, there was a concurrent feeling that the participation in the program needed to be able to widen the opportunities that Native social workers had. Many participants emphasized the importance of a freedom of choice: they wanted to have the option of working on or off the "rez" with Native or non-Native clients. One participant wanted to gain broad experience in a social work program, noting, "I think your degree has to be able to take you inside and outside of our communities" [Participant 06]. Indeed, the "portability" feature inculcated in a first-class education is not lost on Native people nor is the opportunity it affords them to surmount the effects of historical marginalization and colonization 


\section{Rethinking Social Work Education for Indigenous Students}

by allowing full participation as equals in mainstream Canadian society. Another participant highlighted the desire to be able to work with people of diverse backgrounds:

\section{If it's geared for the Native, see that's the one thing, if it's geared for us to be dealing with Native people then we would still stay as \\ Natives and all the material would be pertaining to Natives. Whereas if we were given many different Ethnic groups, meaning non-Native or Native or Black people, type of viewpoints on how to work with them, then we could work off the community. [Participant 05]}

Additionally, participants said that it was important to have coursework that would help Native social workers address social work-specific issues such as managing jobrelated stress and to effectively implement social work practice in one's own community.

\section{Program Delivery}

Participants, who were from Kahnawake and Kanehsatake, also provided input regarding the delivery of a new social work program focused on Native issues offered at McGill. Certificate program participants, most of whom were mature with families, recalled the substantial challenges to involvement in the program, particularly child care, transportation, and working full time. In order for students to succeed, participants felt that it was vital that the program support students in addressing these three issues.

While child care expenses could be supported by financial subsidies, the other two issues could be addressed by program delivery options. Participants described great difficulties in traveling into Montreal. Additionally, some felt that coming to Montreal was as foreign as traveling to another country, and felt that logistical and emotional support would encourage participation in and completion of a BSW degree. To address some of the logistical as well as cultural challenges, there was consensus among participants that the program should be open to offering courses by McGill instructors in Native communities, such as Kahnawake and Kanehsatake. Participants differed in the proportion of courses to be offered in the community, with some wanting more and some wanting fewer courses on the McGill campus. The need to work full time also hindered participation in the program, and participants felt that if the courses were offered in the evenings, on weekends, or in the community, participation would increase. Some participants were interested in online courses and distance learning; however, most felt that face-to-face interaction was an essential part of social work education. One participant stressed the need for interaction among students and instructors:
It's good for a group to come together if they're studying together, whether it's videoconferencing or online distance ed. But at some point I think you have to have that human interaction. What my sister said was one of the best things that came out of the McGill certificate program is that almost on a weekly basis there was a lot of lively discussion on the problems or the social issues impacting the communities and it got pretty lively and she says it was the best part of it. She says because it came out and it was open discussion. [Participant 06]

The preference among the majority of participants was a blended program approach, with courses held on the McGill campus as well as in the community (Kahnawake). Participants also wanted to have some to most of the courses at McGill because they felt it was critical that the program be seen as of the same quality as the regular BSW. One participant noted,

\section{It's good to be able to take courses with a Native slant to it, as opposed to mainstream social work. But I think at the same time I think it's necessary for us to be in mainstream programs, to offer the same to everybody, the same quality of training. [Participant 07]}

All participants felt strongly that educated social work practitioners from their communities were needed to address the crisis issues facing their communities. The suggestions for ways to educate members of Native communities for careers in social work ranged from a redeveloped certificate program at McGill that could stand alone or be linked to entrance into a BSW program as well as a BSW program specifically focused on Aboriginal social work. Additionally, based on feedback on academic preparation, the possibility of a qualifying year was also raised. However, the general trend among participants was that a BSW degree, more than a Certificate, would provide greater benefits for Native social workers and wider opportunities for both the social worker and the community in which he or she worked.

\section{Discussion}

Study findings contribute to a growing identification of the need for more professionally qualified Indigenous workers. In Quebec, only the University of Quebec in Temiscamingue offers Indigenous social work students a degree course in English. All schools of social work whose graduates (Native and non-Native) work in or with Native communities have an obligation to offer a curriculum in which Indigenous culture, social reality, and ways of knowing and teaching are reflected. If we accept that social work is a modernist, Western invention which has largely imported Western thinking from Britain and 
the United States into diverse cultural contexts around the world (Gray, Coats \& Hetherington, 2007), we can use Indigenous ways of knowing, healing and teaching to counter balance the dominant philosophy and pedagogy. A majority of social work graduates will encounter Indigenous people in their future practice. Therefore, it is essential that they fully understand the historical context of the social issues facing Indigenous individuals and communities. During their coursework, they should also learn about the role and contribution of women and Elders in Indigenous communities (e.g., Berman, 2003; Brodribb, 1984; Kulchyski, McCaskill, \& Newhouse, 1999; Stiegelbauer, 1996).

Indigenous students are underrepresented in undergraduate and graduate social work degree programs. Adapting the social work curriculum and program delivery and infusing general courses with Indigenous content in culturally relevant ways will open opportunities to address social issues in First Nations communities and increase the likelihood of enrollment of Aboriginal students. It is not good enough merely to have a single class on Indigenous issues in a BSW curriculum nor should Native peoples been seen as a monolithic group. It is imperative to foster broad community collaboration in the development of the program so that the knowledge of Elders and other traditional people are reflected in the course content and methods of delivery. Such collaboration should make use of resources that reflect the cultural, social, economic, and political realities of the local Native populations.

Native students face multiple barriers in attending mainstream schools. Study findings revealed that participants, even those who had completed the certificate program, had myriad concerns around their ability to succeed in a mainstream social work program. It is clear that a range of support systems need to be put in place, such as child care, support from family, employers, and the community, help with writing and study skills for mature students returning to full-time education, and the opportunity to support each other and share experiences. In light of that, universities that house schools of social work need to be welcoming in a holistic way. This includes making resources available to support Native students throughout their years of study and creating a university environment conducive to their integration into the student body and to their academic success.

\section{Suggestions for Future Research and Practice}

The McGill School of Social Work has been awarded a grant from the Health Canada Aboriginal Health Human Resources Initiative over the years 2007 - 2010. This project - Indigenous Access McGill - is designed to assist the School and the other health disciplines at McGill to give greater support to First Nations and Inuit students already in programs through ongoing mentoring, tutoring, and summer support programs. An aspect of the project will allow the School to examine the BSW curriculum with a view to adding content and pedagogy that will integrate First Nations and Inuit issues. Three areas have been discussed that would allow a program to develop that is more appropriate to the reality of the increasing numbers of Indigenous students entering social work and that might offer non-Indigenous students an opportunity to make a more in-depth study of Indigenous issues during their BSW program.

The key elements of the project should make the BSW program more attractive to Indigenous students who wish to follow a career in social work both in their own communities and elsewhere and to non-Indigenous students with an interest in Indigenous issues. The project also hopes to create a program in which Indigenous and non-Indigenous students can study together and learn from and support each other. The three elements of the program are discussed briefly below.

\section{Curriculum Consultation}

This methodology has been successfully used in other Schools of Social Work. The School has one First Nations Issues course as an elective and some materials in other courses pertaining to First Nations issues at the discretion of individual instructors. A project of curriculum consultation could begin to examine the required courses on the program and gradually add more Indigenous content and pedagogy where appropriate.

\section{Summer Support}

In 2007, the School of Social Work offered a short summer orientation program for potential social work students. The program proved very successful and was much appreciated by participants. The project offers the opportunity to develop a similar program each year for students who have applied and been accepted to the program. It is anticipated that these students could come together for a program of orientation activities in the summer and just before the beginning of classes.

\section{Mentoring and Tutoring Support}

This part of the project is designed through the establishment of a Resources Room and a two-member team (one of whom is First Nations) to offer ongoing mentoring and support to students on the program. This is a direct result of some of the comments offered during the research study by participants in the Certificate program who greatly appreciated the mutual support generated by the group. Individual and group mentoring, individual 


\section{Rethinking Social Work Education for Indigenous Students}

tutoring and all the general resources of the University are available.

The evaluation of this project and the experiences of the students presently studying in the School of Social Work will be a rich resource in terms of future development. There are also a number of future research projects which we hope will grow out of this project, including following graduates of the BSW program into careers in their own communities and elsewhere and explore the impact of the Indigenous Access Project on their practice. The reality is that the majority of First Nations and Inuit BSW graduates will go on to work in organizations or agencies serving children and families. Therefore, another potential study is assessing the impact they will have as Native social workers in their own communities. A potential longitudinal study might examine the impact of Native social workers who use a least restrictive practice approach on the number of Native children in the child welfare system.

\section{Endnotes}

1. For this study, the backgrounds of the two Allied researchers were Scottish, Irish, African American, German, Slovakian, Seminole, Cherokee, and Hungarian.

\section{References}

Berman, T. (2003). Circle of Goods: Women, work, and welfare in a reservation community. Albany, NY: State University of New York Press.

Brodribb, S. (1984). The traditional roles of Native women in Canada and the impact of colonization. The Canadian Journal of Native Studies, 4, 85-103.

Bruyere, G. (1998). Living in another man's house: Supporting Aboriginal learners in social work education. Canadian Social Work Review, 15, 169-176.

Glaser, B., \& Strauss, A. (1967). The discovery of grounded theory. Hawthorne, NY: Aldine.

Gray, M., Coates, J., \& Hetherington, T. (2007). Hearing indigenous voices in mainstream social work. Families in Society: The Journal of Contemporary Social Services, 88, 55-66.

Gray, M. (2005). Dilemmas of international social work: Paradoxical processes in indigenisation, universalism, and imperialism. International Journal of Social Welfare, 14, 231-238.

Kulchyski, P., McCaskill, D., \& Newhouse, D. (1999). (Eds.). In the words of elders: Aboriginal cultures in transition. Toronto: University of Toronto Press.

Lee, B. (1992). Colonialization and community: Implications for First Nations development. Community Development Journal, 27, 211-219.
Lieblich, A., Tuval-Mashiach, R., \& Zilber, T. (1998). Narrative research: Reading, analysis, and interpretation. Thousand Oaks, CA: Sage.

Morrisette, V., McKenzie, B., \& Morrisette, L. (1993). Towards an Aboriginal model of social work practice: Cultural knowledge and traditional practices. Canadian Social Work Review, 10, 91-108.

O'Brien, D., \& Pace, J. (1990). The role of empowerment in social work degree programs for Indigenous Native people: A critique of one school's experience. Canadian Journal of Native Studies, 10, 1-13.

Omidian, P. (2000). Qualitative measures and refugee research: The case of Afghan refugees. In F. L. Ahearn (Ed.), Psychosocial wellness of refugees: Issues in qualitative and quantitative research (pp. 41-66). New York: Berghahn Books.

Padgett, D. K. (1998). Qualitative Methods in Social Work Research: Challenges and Rewards. Thousand Oaks, CA: Sage.

Ryan, J. (1995). Experiencing urban schooling: The adjustment of Native students to the extra-curricular demands of a postsecondary program. Canadian Journal of Native Studies, 15, 211-230.

Sinclair, R. (2004). Aboriginal social work education in Canada: Decolonizing pedagogy for the Seventh Generation. First Peoples Child \& Family Review, 1, 49-61.

Smith, A. F. V., \& Pace, J. M. (1988). The Micmac Bachelor of Social Work Program: Policy direction and development. Canadian Journal of Native Studies, 8, 147-154.

Stiegelbauer, S. M. (1996). What is an Elder? What do Elders do?: First Nation Elders as teachers in culture-based urban organizations. The Canadian Journal of Native Studies, 14, 37-66.

Tuhiwai-Smith, L. (1999). Decolonizing Methodologies: Research and Indigenous Peoples. London: Zed Books Ltd.

Warner, L. S. (2006). Native ways of knowing: Let me count the ways. Canadian Journal of Native Education, 29, 149-164.

Weaver, H. N. (1999). Indigenous people and the social work profession: Defining culturally competent services. Social Work, 44, 217-225. 


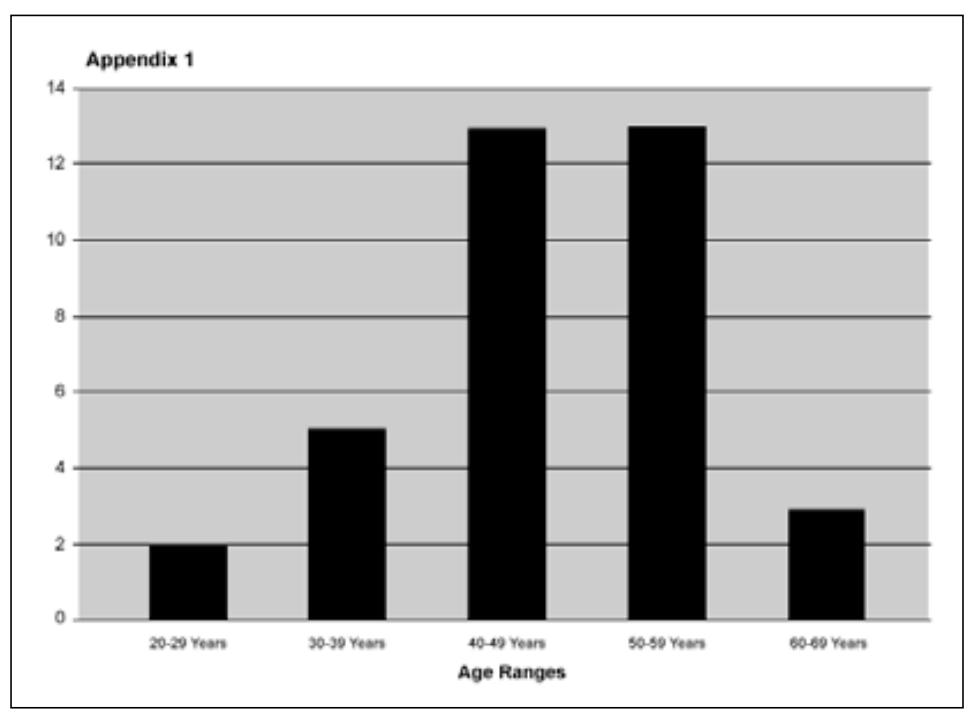

\section{Appendix 2}
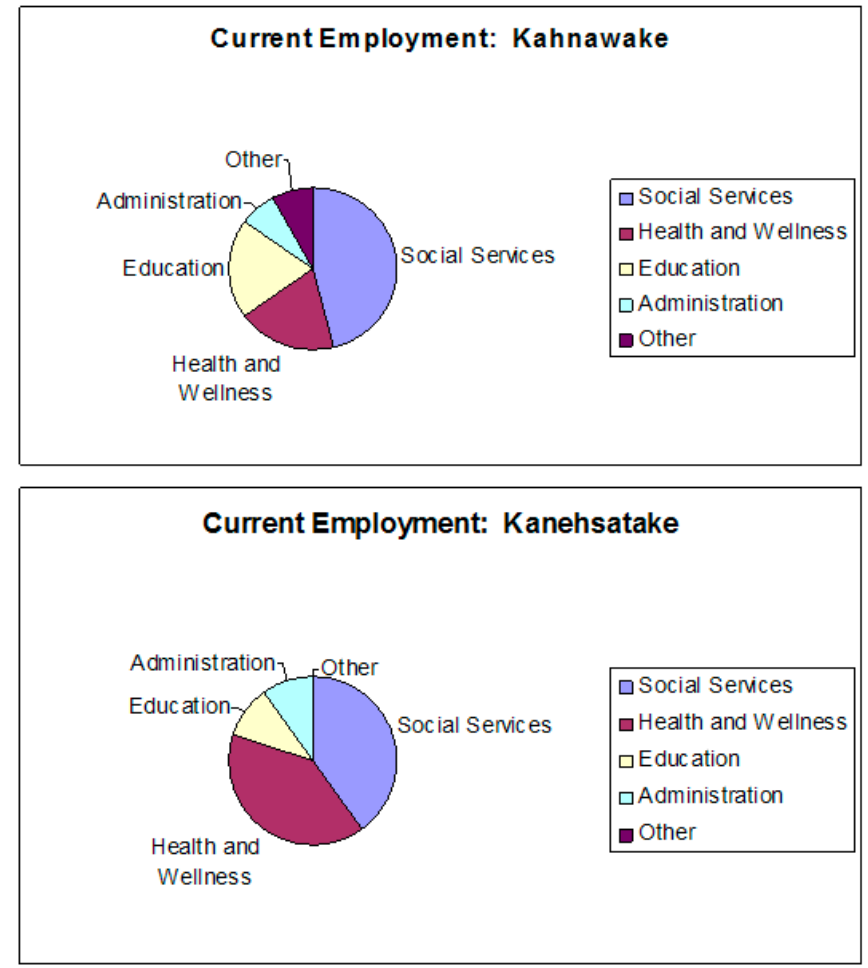